\title{
Analysis of Competence and Service Quality on Customer Satisfaction and Loyalty in Eastern Indonesia Border Tourism
}

\author{
Milcha Handayani Tammubua ${ }^{1}$, Deni Surapto ${ }^{2}$ \\ Faculty of Economics, Universitas Terbuka, Indonesia \\ milcha@ecampus.ut.ac.id, denis@ecampus.ut.ac.id
}

\begin{abstract}
The border tourism between Indonesia and Papua New Guinea is currently in great demand by many tourists. Therefore, this study aims to analyze customer satisfaction and loyalty which are influenced by competence and service quality. To test the direct and indirect effect hypothesis, this study adopts a quantitative research approach. The research instrument used was a questionnaire. The sample of this research was 192 tourists who were visiting the PLBN Skouw tour. The research data were analyzed using Partial Least Squares (PLS) analysis method with SmartPLS3.0 software. The results of this study can prove that competence can have a positive and significant effect on service quality and customer satisfaction. Customer satisfaction has a positive and significant effect on customer satisfaction and loyalty. In addition, customer satisfaction can also mediate the relationship between competence and customer satisfaction. Customer satisfaction is proven to have a positive and significant effect on customer loyalty. Customer satisfaction can also mediate the relationship between service quality and customer loyalty.
\end{abstract}

Keywords

competence; service quality, customer satisfaction; customer loyalty

\section{Introduction}

The Indonesian government through Presidential Regulation No.2 of 2015 concerning the 2015-2019 National Medium-Term Development Plan has prioritized the development agenda for underdeveloped areas and created a special agency to manage state borders, one of which is the state border between Indonesia and Papua New Guinea (Mawarni, 2019). The government is building infrastructure in the border area and developing it into a tourist area known as the Skouw State Border Post (PLBN). With the development of the border area into a place for tourism, it is hoped that it can improve the welfare of the surrounding community, because the condition of the community along the Indonesia-Papua New Guinea border area is mostly still experiencing poverty and low welfare (Usman \& Sairin, 2017).

As a relatively new tourist spot, many tourists are enthusiastic about going to the Skouw PLBN tourist spot. It is recorded that every week nearly 5,000 local and foreign tourists come to visit PLBN Skouw (Amanda, 2017; Fadil, 2017). This number is predicted to increase along with the number of local and foreign tourists who travel to Papua Province as shown in Figure 1. Although in 2015 and 2018 there was a decrease in the number of guests (both Indonesian citizens and foreign nationals) who came to Papua Province, however, in 2019 it has increased again and the number is greater than in previous years (BPS Provinsi Papua, 2019). 


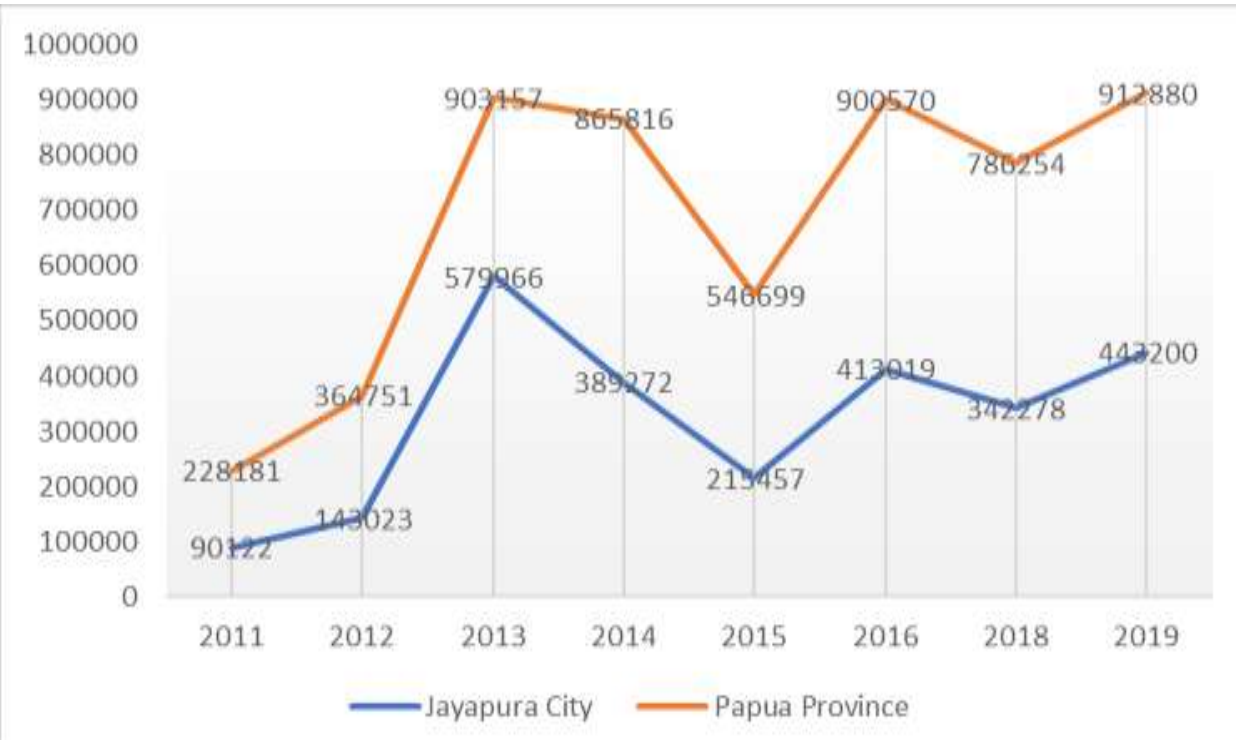

Figure 1. Number of Foreign and Indonesian Guests in Papua Province, 2011-2019

The increasing interest of tourists towards tourism in PLBN Skouw has made the government continue to develop facilities to support tourism services (Fadil, 2017). In addition to the development of tourist facilities, it is important for the government to know the satisfaction and loyalty of tourists because the success of a tourist destination does not only depend on environmental analysis, but also the satisfaction and loyalty of customers or tourists who visit (McKercher \& Prideaux, 2011). Amin and Priansah (2019) stated that Tourism is an industrial sector which is currently got a lot of attention from many countries in the world.

Therefore, this study aims to analyze customer satisfaction and customer loyalty which is influenced by competence and service quality. To improve the competitiveness of tourist attractions in a sustainable manner, it depends on how these tourist attractions provide high quality services that lead to tourist satisfaction and loyalty (Campón-Cerro et al., 2017). In addition to service quality, the competence of employees at tourist attractions also plays an important role because it allows tourists to experience high-quality services and will effectively increase tourist satisfaction (Lin et al., 2017).

\section{Review of Literature}

\subsection{Loyalty}

Customer loyalty refers to accurate and loyal customer trust, which can get more benefits for the company (Reichheld \& Schefter, 2000). Jones and Sasser (1995) proved that customer loyalty can influence customer repurchase intentions and customer loyalty can be classified into two categories, namely long-term loyalty and short-term loyalty. Tourism destination loyalty research has received scholarly interest in the marketing literature (Gallarza et al., 2013; Kim et al., 2013; Vinh \& Long, 2013). Destination loyalty is the main result of the successful delivery of quality tourism services and experiences in a tourism destination (Akroush et al., 2016). 


\subsection{Competence}

According to Spencer and Spencer (1993), competence is a person's performance in work as seen from the way he thinks, behaves and behaves. The concept of competence was originally introduced in social psychology studies which was later extended to marketing and business contexts (Aaker et al., 2010; Scott et al., 2013). In relation to organizational behavior, competent people are people who have succeeded in doing their job well (Cuddy et al., 2007). According to Boshoff and Allen (2000), employees who do not have the necessary competencies in the workplace are likely to fail to meet customer needs or provide quality and satisfactory service.

Previous empirical findings have proven that employee competence has a positive effect on service quality (Cholkongka, 2019; Rosmika \& Nurhaida, 2017; Wei \& Ho, 2019). Employees must have the ability and knowledge in their field of work in order to be able to provide professional services (Harahap et al., 2020). Wu et al. (2015) found that competent front-line employees will be able to communicate and understand customer needs so as to make customers believe that the company can provide reliable and accurate service quality. Related to the tourism sector, Lin et al. (2017) and Ninpradith et al. (2018) prove that the competence of the tour guide will have a direct positive effect on the level of service quality. Based on the findings of previous research, a research hypothesis can be formulated, namely:

H1: Competence has a positive effect on service quality

Employee competence is an important factor that affects service quality and tourist satisfaction (Lin et al., 2017). Some researchers also found that employee competence has a positive effect on customer satisfaction (Anwar et al., 2020; Ninpradith et al., 2018; Rosmika \& Nurhaida, 2017). Front-line employees play an important role in providing service to customers and can influence customer perceptions of service quality and satisfaction (Brady \& Cronin, 2001). Several researchers have also proven that a number of specific competencies such as employee emotional competence (Delcourt et al., 2013) and intercultural competence (Ihtiyar et al., 2014) have a direct and significant effect on customer satisfaction. With the competencies possessed by employees, employees will be able to meet customer needs and develop relationships with customers so that customers are satisfied (Vargo \& Lusch, 2014). Therefore, the second hypothesis is proposed as follows:

H2: Competence has a positive effect on customer satisfaction

\subsection{Quality of Service}

Service quality is defined by some researchers as the extent to which the services provided meet customer needs or expectations (Dotchin \& Oakland, 1994). Service quality is an important antecedent of customer satisfaction, and superior service quality will result in higher customer satisfaction and vice versa (Cronin \& Taylor, 1992). By various studies, service quality is a competitive differentiator that can be used to improve customer satisfaction (Curry \& Gao, 2012; Seth et al., 2005). Customers will feel satisfied if the service experience is in accordance with the expected service, because high quality service can increase customer satisfaction (Parasuraman et al., 1985).

Previous researchers have proven the positive effect of service quality on customer satisfaction (Kant \& Jaiswal, 2017; Kassim \& Asiah Abdullah, 2010; Saleem \& Raja, 2014; Yeo et al., 2015). who examined customer satisfaction in the tourist area of Jordan showed that service quality consisting of destination facilities, destination accessibility, and destination attractiveness is a good significant predictor of tourist satisfaction. In addition, Latiff and Imm (2015) also found that there was a significant relationship 
between accommodation service quality, hospitality, entertainment, transportation, taxi service quality and overall tourist satisfaction. Based on the theory and empirical findings, a third hypothesis is proposed:

H3: Service quality has a positive effect on customer satisfaction

Previous empirical findings indicate that a number of employee competencies make a positive contribution to service quality ratings, such as helpfulness, communication skills, and maintaining a neat and professional appearance (Cholkongka, 2019). In addition, service quality has also been shown to play an important role in increasing customer satisfaction (Al-Ababneh, 2013; Batouei et al., 2019). The level of service quality in relation to the competence of tour guides will have a direct positive effect on the level of tourist satisfaction (Ninpradith et al., 2018). In addition, several previous researchers have used service quality as a mediating variable and it has been proven significant that service quality can mediate the relationship between customer relationship management (Mwirigi, 2019) and customer-oriented employees ( $\mathrm{Li}$ et al., 2019) on customer satisfaction. More specifically, Rosmika and Nurhaida (2017) prove that service quality can mediate the relationship between competence and customer satisfaction. Therefore this study assumes that service quality can mediate the relationship between competence and customer satisfaction, and the next hypothesis proposed is:

H4: Service quality can mediate the relationship between competence and customer satisfaction

The success of customer-centered organizations is highly dependent on creating business value and providing quality service that leads to customer satisfaction and loyalty (Makanyeza and Mumiriki, 2015). Previous empirical findings have proven the direct effect of service quality on customer loyalty (Saleem \& Raja, 2014). Good quality service will make customers come back to buy products / services, be less sensitive to price changes, and tell others about their beneficial experiences (Slack \& Singh, 2020). The findings of Osman (2013) prove that customer loyalty among tourists can be increased by focusing on factors that improve service quality. These results were confirmed by Akroush et al. (2016) who also found that service quality in tourist destinations has a positive and significant effect on tourist loyalty. Thus, the fifth hypothesis is proposed:

H5: Service quality has a positive effect on customer loyalty

\subsection{Customer Satisfaction}

Customer satisfaction is a psychological condition of the value felt by customers of a product or service (Howard \& Sheth, 1969). According to Hemple (1997), customer satisfaction is determined by the degree of difference in perceived value with the actual results of the purchase of goods or services. In the tourism sector, satisfaction is the expectation before the trip and the experience after the trip, which consists of the emotional state after the trip (Baker \& Crompton, 2000). In short, satisfaction is a tourist's expectation of a tourist spot based on the image and information he has previously obtained, and an assessment of the results of the tourist experience at the tourist spot (Neal \& Gursoy, 2008).

Lau and Cheung (2013) explained that meeting customer expectations will not only provide satisfaction but develop customer loyalty. Previous empirical findings have proven a positive and significant effect of customer satisfaction on customer loyalty (Fida et al., 2020; Gritti \& Foss, 2010; Mulyana \& Prayetno, 2018; Osman, 2013; Saleem \& Raja, 2014; Slack \& Singh, 2020). Customers will be loyal if they are satisfied with the service and experience provided (Batouei et al., 2019). Gogoi (2020) found that satisfied travelers 
share their positive experiences at tourist attractions by word of mouth. Based on these empirical findings, the sixth hypothesis is proposed:

H6: Customer satisfaction has a positive effect on customer loyalty

Research Slack and Singh (2020) found that customer satisfaction can partially mediate the relationship between service quality and customer loyalty. Kheng et al. (2010) found that customer satisfaction can mediate the relationship between service quality dimensions consisting of tangibles, reliability, responsiveness, empathy, and assurance of customer loyalty. These findings are also supported by other researchers who prove that customer satisfaction can mediate the relationship between service quality and customer loyalty (Chu et al., 2012; Osman, 2013). Based on these empirical findings, the final hypothesis proposed in this study is:

H7: Customer satisfaction can mediate the relationship between service quality and customer loyalty

The seven hypotheses proposed in this study are summarized in the following research model:

$\mathrm{H} 7$

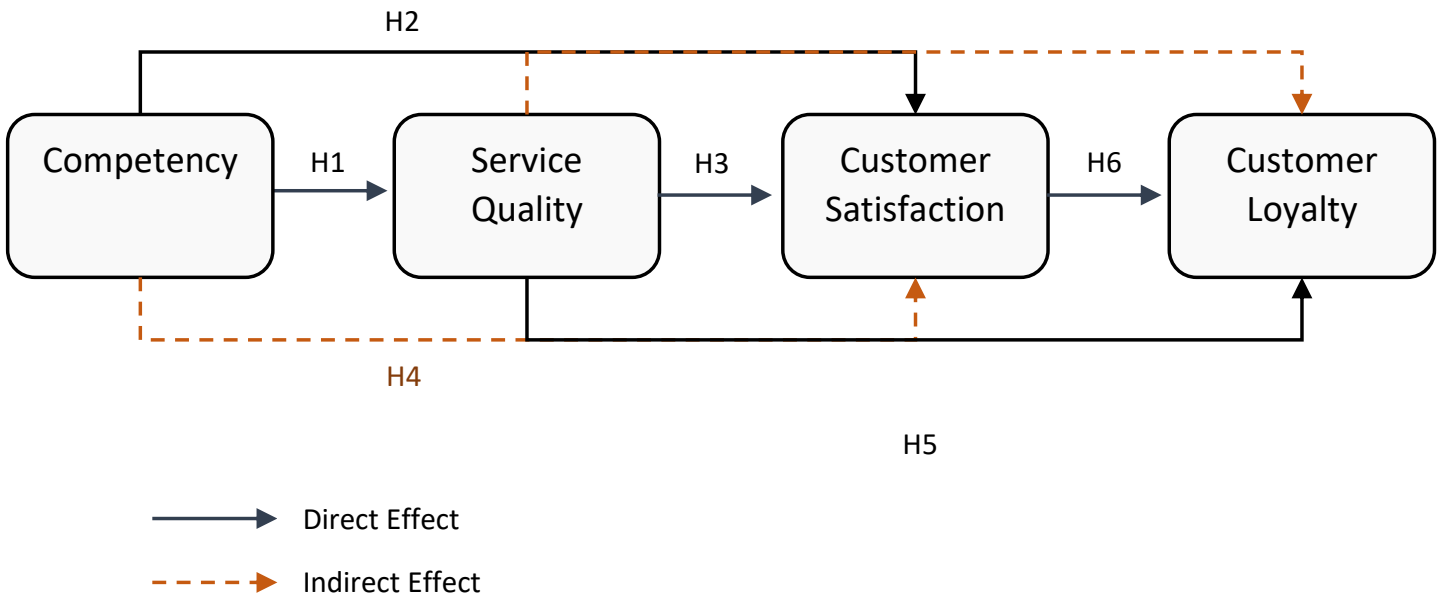

Figure 2. Research Model

\section{Research Methods}

To test the direct and indirect effect hypothesis, this study adopts a quantitative research approach. The research instrument used is in the form of a questionnaire because it can be an effective tool to measure the relatively large number of subjects' behavior, attitudes, preferences, opinions and intentions (Fraley et al., 2000). The questionnaire was arranged on a 5-point Likert scale from 1 (strongly disagree) to 5 (strongly agree). Researchers distributed questionnaires directly to tourists who were visiting the Skouw Integrated National Border Post (PLBN) tour. The questionnaire was distributed to 200 tourists, but only 192 can be used for analysis in this study.

The research data were analyzed using Partial Least Squares (PLS) analysis method with SmartPLS3.0 software. To test the research conceptual framework, a two-step approach was carried out, namely testing the external measurement model and testing the inner structural model. Compared to a covariance-based structural equation model (SEM), PLS requires a relatively small sample size and is more suitable for exploratory analysis (Joe F Hair et al., 2011). 


\section{Result and Discussion}

This study took 192 tourists from the Skouw Integrated National Border Post (PLBN) as respondents. Table 1 presents the characteristics of the respondents in detail. Based on the information in table 1, it can be seen that the difference between male tourists is not much different from the number of female tourists, so it can be said that the number of male and female tourists is almost equal. Then the respondents were dominated by unmarried tourists $(53.40 \%)$, with a high school education level $(78 \%)$, and other types of work (not civil servants, private workers, entrepreneurs, or housewives).

Table 1. Demographic Characteristics of Respondents

\begin{tabular}{|c|c|c|c|}
\hline Category & Alternative Answers & $\begin{array}{c}\text { Number of } \\
\text { Respondents }\end{array}$ & $\begin{array}{c}\text { Percent } \\
(\%)\end{array}$ \\
\hline \multirow{2}{*}{ Gender } & Man & 98 & 50,80 \\
\hline & Women & 94 & 49,20 \\
\hline \multirow{2}{*}{ Marital status } & Married & 89 & $46,60 \%$ \\
\hline & Single & 103 & $53,40 \%$ \\
\hline \multirow{4}{*}{ Level of education } & High school & 150 & 78 \\
\hline & 3-year diploma & 24 & 12,60 \\
\hline & Bachelor degree) & 18 & 9,40 \\
\hline & Bachelor s2) & 0 & 0 \\
\hline \multirow{5}{*}{ Profession } & Civil servants & 59 & 30,90 \\
\hline & Private & 29 & 15,20 \\
\hline & entrepreneur & 6 & 3,10 \\
\hline & IRT & 12 & 6,30 \\
\hline & Others & 85 & 44,50 \\
\hline
\end{tabular}

As presented in table 2, tourists get the most information about the Skouw Integrated PLBN tourist attractions from friends (58.1). This is in line with the findings of Bitner and Hubbert (1994) and Faullant et al. (2008) that one form of customer loyalty is to recommend to others or known as word of mouth promotion.

Then tourists are attracted to visit because of the natural beauty (35.6\%). The natural beauty found in Papua gives more value to the border areas where protected forests whose habitat is still maintained are supported by the local wisdom of the inhabitants. The most popular visiting days for tourists are Sunday (41.4\%) and Saturday (33.5\%). National holidays are used by tourists to visit border tours. Information obtained in the field, Tuesday and Thursday are trade market days between the two countries. Most tourists visit suddenly without a prior plan $(83.8 \%)$.

Table 2. Characteristics of Respondents Regarding Tourist Attractions

\begin{tabular}{cccc}
\hline \multirow{2}{*}{ Question } & Alternative Answers & $\begin{array}{c}\text { Number of } \\
\text { Respondents }\end{array}$ & $\begin{array}{c}\text { Percent } \\
(\boldsymbol{\%})\end{array}$ \\
\hline \multirow{3}{*}{ Resources } & Friend & 112 & 58,10 \\
& Family & 24 & 12,60 \\
\cline { 2 - 3 } & Brochure & 6 & 3,10 \\
\cline { 2 - 3 } & & &
\end{tabular}




\begin{tabular}{|c|c|c|c|}
\hline & Social media & 15 & 7,90 \\
\hline & Internet & 25 & 13,10 \\
\hline & Print media & 0 & 0 \\
\hline \multirow{5}{*}{ Visiting Interest } & Tour packages & 24 & 12,60 \\
\hline & Natural Beauty & 68 & 35,60 \\
\hline & Ease of Access & 44 & 23 \\
\hline & Electronic Media & 26 & 13,60 \\
\hline & Affordable prices & 22 & 11,50 \\
\hline \multirow{7}{*}{ Visit Day } & Sunday & 79 & 41,40 \\
\hline & Saturday & 64 & 33,50 \\
\hline & Friday & 6 & 3,10 \\
\hline & Thursday & 0 & 0 \\
\hline & Wednesday & 0 & 0 \\
\hline & Tuesday & 3 & 1,60 \\
\hline & Monday & 9 & 4,70 \\
\hline \multirow{2}{*}{ Visiting Decision } & Well planned & 31 & 16,20 \\
\hline & Sudden & 161 & 83,80 \\
\hline
\end{tabular}

From table 1 above, the model has good discriminant validity if each of the loading indicator values of a latent variable is greater than the other correlated variables. The crossloading value in this research for each indicator is greater than the other latent variables. This shows that each variable has good discriminant validity.

\subsection{Measurement Model}

This study uses a reflective measurement model, so that reliability and validity tests need to be carried out to ensure its suitability for investigations with SEM-PLS (Joe F Hair et al., 2011). Convergent validity test seen from outer loading and Average Variance Extracted (AVE) value. According to Chin et al. (2008), a feasible outer loading has a value above 0.6 and an AVE above 0.5. As presented in table 3, all items have an outer loading value of more than 0.6 and all variables have an AVE value above 0.5 . There are five items that were removed from the model because they did not meet the outer loading criteria, namely CS1, CS2, CS3, CS4, and CS7. Furthermore, the measurement of reliability is seen from the composite reliability (CR) value with the eligibility criteria above 0.7 (J.F. Hair et al., 2016). The test results in table 3 show that all variables have a $\mathrm{CR}$ value> 0.7 . So that all variables meet the reliability requirements.

Table 3. Factor Loading and Reliability Coefficients

\begin{tabular}{|c|c|c|c|}
\hline Variable & Loading & AVE & $\mathbf{C R}$ \\
\hline Competency & & 0,736 & 0,893 \\
\hline CM1 & 0,863 & & \\
\hline CM2 & 0,872 & & \\
\hline CM3 & 0,839 & & \\
\hline Service Quality & & 0,791 & 0,919 \\
\hline PR1 & 0,896 & & \\
\hline
\end{tabular}




\begin{tabular}{|c|c|c|c|}
\hline PR2 & 0,876 & & \\
\hline PR3 & 0,897 & & \\
\hline Customer Satisfaction & & 0,510 & 0,912 \\
\hline CS5 & 0,735 & & \\
\hline CS6 & 0,691 & & \\
\hline CS8 & 0,752 & & \\
\hline CS9 & 0,695 & & \\
\hline CS10 & 0,788 & & \\
\hline CS11 & 0,785 & & \\
\hline CS12 & 0,630 & & \\
\hline CS13 & 0,680 & & \\
\hline CS14 & 0,659 & & \\
\hline CS15 & 0,706 & & \\
\hline Customer Loyalty & & 0,600 & 0,818 \\
\hline L1 & 0,821 & & \\
\hline $\mathrm{L} 2$ & 0,766 & & \\
\hline L3 & 0,735 & & \\
\hline
\end{tabular}

Furthermore, to ensure that the variables under study do not have unidimensional properties (Chin et al., 2008; Hair et al., 2016), this study evaluates the validity of the discriminant through the heterotrait monotrait ratio (HTMT). Table 4 shows that all research variables are valid because they have an HTMT value below 0.9 (Hair et al., 2016). Thus, the selected variables meet the main requirements of this study.

Table 4. Heterotrait-Monotrait Ratio (HTMT)

\begin{tabular}{lcccc}
\hline Competency & $\begin{array}{c}\text { Customer } \\
\text { Loyalty }\end{array}$ & $\begin{array}{c}\text { Customer } \\
\text { Satisfaction }\end{array}$ & $\begin{array}{c}\text { Service } \\
\text { Quality }\end{array}$ \\
\hline Competency & & & & \\
\hline Customer Loyalty & 0,586 & & & \\
\hline Customer Satisfaction & 0,880 & 0,597 & & \\
\hline Service Quality & 0,793 & 0,596 & 0,850 & \\
\hline
\end{tabular}

Based on table 4, it shows that reward has a very weak effect on student satisfaction, then satisfaction has a moderate effect on student loyalty

\subsection{Structural Model}

The evaluation of the structural model is analyzed by looking at the R-Square value. The R-Square of the first line model is 0.244 , which means that service quality and customer satisfaction only explain $24.4 \%$ customer loyalty, while the rest is influenced by other variables. The second model is 0.685 which means that competency and service quality only affect $68.5 \%$ and the rest is influenced by other variables that are not studied. The third model is 0.451 , which means that employee competence affects service quality by $45.1 \%$. According to Chin et al. (2008), a) if $\mathrm{R} 2=0.67$ then the model is substantial (strong); b) If R2 $=0.33$ then the model is moderate (medium); and c) If $\mathrm{R} 2=0.19$ then the 
model is weak (bad). Therefore it can be concluded that only model 1 is classified as moderate (moderate), while model 2 and model 3 are considered substantial (strong).

Table 5. R-Square Value

\begin{tabular}{lcc}
\hline & R Square & $\begin{array}{c}\text { R Square } \\
\text { Adjusted }\end{array}$ \\
\hline Customer Loyalty & 0.244 & 0.236 \\
\hline Customer Sastisfaction & 0.685 & 0.682 \\
\hline Service Quality & 0.451 & 0.448 \\
\hline
\end{tabular}

The overall results of hypothesis testing are described in Figure 3 and indicate that this study can support all the hypotheses proposed. The analysis of the results of the first hypothesis shows that the path coefficient value is 0.672 and $p<0.001$, which means that there is a positive and significant effect of competence on service quality. This result is in line with the findings of previous research which also found that the competencies possessed by employees can have a positive effect on the quality of services provided

This is indicated by the path coefficient value of 0.094 with a P-value of $0.600>0.05$, which means it is not significant (Cholkongka, 2019; Rosmika \& Nurhaida, 2017; Wei \& Ho, 2019). Employees on duty at the Skouw State Border Post tourist spot have good knowledge of these tourist attractions because they are their home areas and have good service capabilities because they have been given prior training by the government. With these competencies, tourists get good service quality. Employees who have the necessary competencies will be able to provide quality services to customers (Boshoff \& Allen, 2000).

Furthermore, the results of this study support the second hypothesis which is shown by the path coefficient value of 0.459 and $p<0.001$ so that it is evident that competence has a positive effect on customer satisfaction. These findings support the research results Delcourt et al. (2013), Ihtiyar et al. (2014), Rosmika and Nurhaida (2017), Ninpradith et al. (2018), and Anwar et al. (2020), Ninpradith et al. (2018), dan Anwar et al. (2020) and Employee competence can directly affect customer satisfaction because employees can meet customer expectations or needs. Employees at the PLBN Skouw tour have multilingual competence, namely being able to speak according to the Papuan language, Indonesian language, Papua New Guinea language, and English. With this capability, it can provide satisfaction for tourists who come from outside Papua and from abroad.

The results of further hypothesis analysis indicate that service quality has a positive and significant effect on customer satisfaction, as seen from the path coefficient of 0.446 and $\mathrm{p}$-value $<0.001$. These findings support the third hypothesis and are in line with the findings of previous researchers (Kant \& Jaiswal, 2017; Saleem \& Raja, 2014; Yeo et al., 2015). The quality of services provided at PLBN Skouw meets the expectations of tourists so they are satisfied. Thus, it is important to always improve service quality standards in order to increase customer satisfaction. 


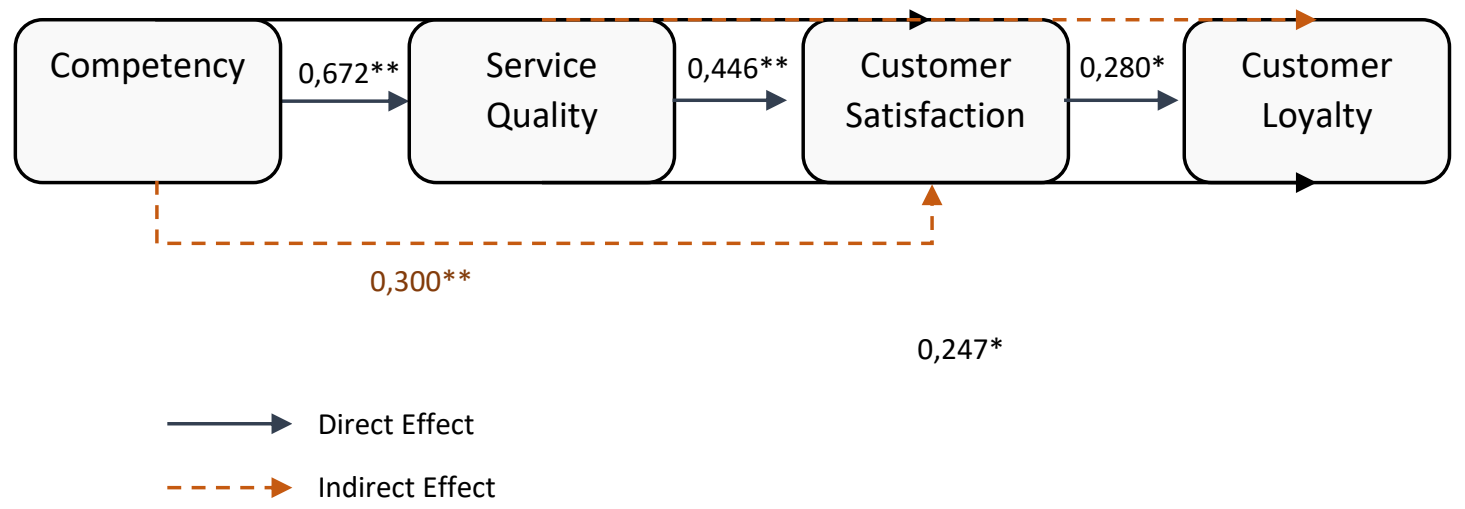

Note: $* \mathrm{p}<0,05 * * \mathrm{p}<0,01$

Figure 3. Hypothesis Testing Results

The results of testing the fifth hypothesis indicate that the path coefficient has a value of 0.247 and $p<0.05$, which means that there is a positive and significant effect of service quality on customer loyalty. This finding is in line with previous research which also found a positive effect of service quality on customer loyalty (Saleem \& Raja, 2014; Slack \& Singh, 2020). Tourists who visit get a good quality of service so they want to come back to visit PLBN Skouw tours and recommend it to friends or other people. This result is also evident from the respondents' answers which show that they get the most information about Skouw PLBN tours from friends. The desire to return and recommend to others is a form of customer loyalty (Akroush et al., 2016; Jones \& Sasser, 1995).

Furthermore, the results of testing the sixth hypothesis indicate that customer satisfaction has a positive effect on customer loyalty as seen from the path coefficient value of 0.280 and $\mathrm{p}<0.05$. These results support previous research that found similar results (Fida et al., 2020; Gritti \& Foss, 2010; Mulyana \& Prayetno, 2018; Osman, 2013; Saleem \& Raja, 2014; Slack \& Singh, 2020). Because the satisfaction that results from higher expectations from visitors and the feeling of wanting to return to the same place and can influence other people to visit again.

Then the results of testing the mediation hypothesis are shown in table 6 . The results of testing the fourth hypothesis indicate that service quality can partially mediate the relationship between competence and customer satisfaction. According to Hair et al. (2010), if (a), (b), and (c) have a significant direct effect, then it means partial mediation. The findings of this fourth hypothesis are in line with the research of Rosmika and Nurhaida (2017) which also proves that service quality can mediate the relationship between competence and customer satisfaction. Employees' competencies provide satisfactory service quality that helps influence customer satisfaction.

The results of further mediation hypothesis testing also show that customer satisfaction partially mediates the relationship between service quality and customer loyalty, this supports the seventh hypothesis. This finding is in line with the research of Slack and Singh (2020), Kheng et al. (2010), Chu et al. (2012), and Osman (2013). Tourists get quality service so that they feel satisfied and finally loyal or want to come back and recommend PLBN Skouw tours to others. 
Table 6. Results of Mediation Testing

\begin{tabular}{|c|c|c|c|c|c|}
\hline $\begin{array}{l}\text { Hypot } \\
\text { hesis }\end{array}$ & Model & $\begin{array}{c}\text { Path } \\
\text { Coefficient }\end{array}$ & $\begin{array}{c}\text { P-Values } \\
\text { Direct } \\
\text { Effect }\end{array}$ & $\begin{array}{c}\text { P-Values } \\
\text { Indirect } \\
\text { Effect }\end{array}$ & Information \\
\hline \multirow[t]{3}{*}{ H4 } & $\begin{array}{l}\text { (a) Competency } \rightarrow \\
\text { Service Quality }\end{array}$ & 0,672 & 0,000 & & \multirow{3}{*}{$\begin{array}{c}\mathrm{a}, \mathrm{b}, \text { and } \mathrm{c} \\
\text { significant }= \\
\text { partial mediation }\end{array}$} \\
\hline & $\begin{array}{l}\text { (b) Service Quality } \rightarrow \\
\text { Customer Satisfaction }\end{array}$ & 0,446 & 0,000 & 0,000 & \\
\hline & $\begin{array}{l}\text { (c) Competency } \rightarrow \\
\text { Customer Satisfaction }\end{array}$ & 0,459 & 0,000 & & \\
\hline \multirow[t]{3}{*}{$\mathrm{H} 7$} & $\begin{array}{l}\text { (a) Service Quality } \rightarrow \\
\text { Customer Satisfaction }\end{array}$ & 0,446 & 0,000 & & \multirow{3}{*}{$\begin{array}{c}\mathrm{a}, \mathrm{b} \text {, and } \mathrm{c} \\
\text { significant }= \\
\text { partial mediation }\end{array}$} \\
\hline & $\begin{array}{l}\text { (b) Customer } \\
\text { Satisfaction } \rightarrow \\
\text { Customer Loyalty }\end{array}$ & 0,280 & 0,026 & 0,037 & \\
\hline & $\begin{array}{l}\text { (c) Service Quality } \rightarrow \\
\text { Customer Loyalty }\end{array}$ & 0,247 & 0,031 & & \\
\hline
\end{tabular}

\section{Conclusion}

The results of this study can prove that competence can have a positive and significant effect on service quality and customer satisfaction. So it is important to improve employee competence through training and development because it will have an impact on service quality and customer satisfaction. Then customer satisfaction has a positive and significant effect on customer satisfaction and loyalty. In addition, customer satisfaction can also mediate the relationship between competence and customer satisfaction. Service quality is very important and must be continuously reviewed and improved. Customer satisfaction is proven to have a positive and significant effect on customer loyalty. Customer satisfaction can also mediate the relationship between service quality and customer loyalty.

The findings of this study provide theoretical and practical contributions. From a theoretical perspective, this study extends the literature by examining the relationship between competence, service quality, customer satisfaction, and customer loyalty. From a practical point of view, this research has managerial implications for the PLBN Skouw tourism manager. Tourism managers must always pay attention to the competencies possessed by employees and make regular training and development programs so that employees have competencies that are relevant to the conditions or challenges of future tourist attractions. Then, tourism managers must apply high service standards so that they can provide quality services to tourists. Improving service quality can also be done by adding facilities such as opening special mode routes to border tourism and nature tourism as well as introducing local culture and wisdom.

PLBN Skouw tourism managers also need to carry out promotions via the internet on a large scale, cooperate or invite well-known travelers who have a large following on social media, hold large events or organize activities to show the existence of these tourist attractions so that they can increase the number of tourists who come. Because based on the results of this study, visitors get more information from friends. Information from social media, internet, and brochures is still lacking. 


\section{References}

Aaker, J., Vohs, K. D., \& Mogilner, C. (2010). Nonprofits Are Seen as Warm and ForProfits as Competent: Firm Stereotypes Matter. Journal of Consumer Research, 37(2), 224-237. https://doi.org/10.1086/651566

Akroush, M. N., Jraisat, L. E., Kurdieh, D. J., AL-Faouri, R. N., \& Qatu, L. T. (2016). Tourism service quality and destination loyalty - the mediating role of destination image from international tourists' perspectives. Tourism Review, 71(1), 18-44. https://doi.org/10.1108/TR-11-2014-0057

Al-Ababneh, M. M. (2013). Service quality and its impact on tourist satisfaction. Institute of Interdisciplinary Business Research, 4(12), 164-177.

Amanda, G. (2017). Setiap Pekan 5.000 Wisatawan Padati Pos Lintas Batas Negara. nasional.republika.co.id.

https://nasional.republika.co.id/berita/nasional/daerah/17/09/15/owaxt8423-setiappekan-5000-wisatawan-padati-pos-lintas-batas-negara

Amin, M. A. S., Priansah, P. (2019). Marketing Communication Strategy To Improve Tourism Potential. Budapest International Research and Critics Institute-Journal (BIRCI-Journal) Vol 2, No 4, Page: 160-166

Anwar, Y., Ferine, K. F., \& Sihombing, N. S. (2020). Competency of Human Resources and Customer Trust on Customer Satisfaction and Its Consequence on Customer Retention in the Hospitality Industry North Sumatra. Journal of Environmental Management and Tourism, 11(6), 1515-1519. https://doi.org/10.14505/jemt.11.6(46).22

Baker, D. A., \& Crompton, J. L. (2000). Quality, satisfaction and behavioral intentions. Annals of Tourism Research, 27(3), 785-804. https://doi.org/10.1016/S01607383(99)00108-5

Batouei, A., Iranmanesh, M., Nikbin, D., \& Hyun, S. S. (2019). Flight anxiety: investigating the role of airline service quality and flight crew's competence. Asia Pacific Journal of Tourism Research, 24(7), 710-724. https://doi.org/10.1080/10941665.2019.1630457

Bitner, M. J., \& Hubbert, A. R. (1994). Encounter satisfaction versus overall satisfaction versus quality. In Service quality: New directions in theory and practice (Vol. 34, Nomor 2, hal. 72-94). California: Sage Publications.

Boshoff, C., \& Allen, J. (2000). The influence of selected antecedents on frontline staff's perceptions of service recovery performance. International Journal of Service Industry Management, 11(1), 63-90. https://doi.org/10.1108/09564230010310295

BPS Provinsi Papua. (2019). Jumlah Tamu WNA dan WNI Menurut Golongan Hotel dan Kabupaten/Kota di Papua, 2011-2019. https://papua.bps.go.id/dynamictable/2017/09/11/94/jumlah-tamu-wna-dan-wnimenurut-golongan-hotel-dan-kabupaten-kota-di-papua-2011-2016.html

Brady, M. K., \& Cronin, J. J. (2001). Customer Orientation: Effects on Customer Service Perceptions and Outcome Behaviors. Journal of Service Research, 3(3), 241-251. https://doi.org/10.1177/109467050133005

Campón-Cerro, A. M., Hernández-Mogollón, J. M., \& Alves, H. (2017). Sustainable improvement of competitiveness in rural tourism destinations: The quest for tourist loyalty in Spain. Journal of Destination Marketing \& Management, 6(3), 252-266. https://doi.org/10.1016/j.jdmm.2016.04.005 
Chin, W. W., Peterson, R. A., \& Brown, S. P. (2008). Structural Equation Modeling in Marketing: Some Practical Reminders. Journal of Marketing Theory and Practice, 16(4), 287-298. https://doi.org/10.2753/MTP1069-6679160402

Cholkongka, N. (2019). Identification of Service Quality Competency Framework for The Lounge Attendants: a Case of A Privately-Owned Airline in Thailand. $A B A C$ Journal, 39(4), 123-150.

Chu, P.-Y., Lee, G.-Y., \& Chao, Y. (2012). Service quality, customer satisfaction, customer trust, and loyalty in an e-banking context. Social Behavior and Personality: an international journal, 40(8), 1271-1283. https://doi.org/10.2224/sbp.2012.40.8.1271

Cronin, J. J., \& Taylor, S. A. (1992). Measuring Service Quality: A Reexamination and Extension. Journal of Marketing, 56(3), 55-68. https://doi.org/10.1177/002224299205600304

Cuddy, A. J. C., Fiske, S. T., \& Glick, P. (2007). The BIAS map: behaviors from intergroup affect and stereotypes. Journal of personality and social psychology, 92(4), 631-648. https://doi.org/10.1037/0022-3514.92.4.631

Curry, N., \& Gao, Y. (2012). Low-Cost Airlines-A New Customer Relationship? An Analysis of Service Quality, Service Satisfaction, and Customer Loyalty in a LowCost Setting. Services Marketing Quarterly, 33(2), 104-118. https://doi.org/10.1080/15332969.2012.662457

Delcourt, C., Gremler, D. D., van Riel, A. C. R., \& van Birgelen, M. (2013). Effects of perceived employee emotional competence on customer satisfaction and loyalty. Journal of Service Management, 24(1), 5-24. https://doi.org/10.1108/09564231311304161

Dotchin, J. A., \& Oakland, J. S. (1994). Total Quality Management in Services. International Journal of Quality \& Reliability Management, 11(3), 27-42. https://doi.org/10.1108/02656719410056468

Fadil, V. (2017). Tiap Pekan, 5.000 Wisatawan Kunjungi Perbatasan RI-PNG. wartaekonomi.co.id. https://www.wartaekonomi.co.id/read154572/tiap-pekan-5000wisatawan-kunjungi-perbatasan-ripng.html

Faullant, R., Matzler, K., \& Füller, J. (2008). The impact of satisfaction and image on loyalty: the case of Alpine ski resorts. Managing Service Quality: An International Journal, 18(2), 163-178. https://doi.org/10.1108/09604520810859210

Fida, B. A., Ahmed, U., Al-Balushi, Y., \& Singh, D. (2020). Impact of Service Quality on Customer Loyalty and Customer Satisfaction in Islamic Banks in the Sultanate of Oman. SAGE Open, $10(2), \quad 2158244020919517$. https://doi.org/10.1177/2158244020919517

Fraley, R. C., Waller, N. G., \& Brennan, K. A. (2000). An item response theory analysis of self-report measures of adult attachment. Journal of personality and social psychology, 78(2), 350-365. https://doi.org/10.1037/0022-3514.78.2.350

Gallarza, M. G., Gil Saura, I., \& Arteaga Moreno, F. (2013). The quality-value-satisfaction-loyalty chain: relationships and impacts. Tourism Review, 68(1), 3-20. https://doi.org/10.1108/16605371311310048

Gogoi, D. B. J. (2020). Service quality measures: How it impacts customer satisfaction and loyalty. International Journal of Management (IJM), 11(3), 354-365.

Gritti, P., \& Foss, N. (2010). Customer satisfaction and competencies: an econometric study of an Italian bank. Applied Economics Letters, 17(18), 1811-1817. https://doi.org/10.1080/13504850903357335 
Hair, J.F., Black, W. C., Babin, B. J., \& Anderson, R. E. (2010). Multivariate Data Analysis. New Jersey, Prentice-Hall.

Hair, J.F., Hult, G. T. M., Ringle, C., \& Sarstedt, M. (2016). A Primer on Partial Least Squares Structural Equation Modeling (PLS-SEM) (2 ed.). Los Angeles: Sage.

Hair, Joe F, Ringle, C. M., \& Sarstedt, M. (2011). PLS-SEM: Indeed a Silver Bullet. Journal of Marketing Theory and Practice, 19(2), 139-152. https://doi.org/10.2753/MTP1069-6679190202

Harahap, R. A., Priscilla, F., \& Wijaya, M. (2020). Effect of Competence, Communication and Job Stress Towards Service Quality PT. Sukses Motor Globalindo. Journal of Research in Business, Economics, and Education, 2(4), 775-783.

Hemple, D. J. (1997). Consumer satisfaction with the home buying process: Conceptualization and measurement. In The conceptualization of consumer satisfaction and dissatisfaction (hal. 7-15). Cambridge, MA: Marketing Science Institute.

Howard, J. A., \& Sheth, J. N. (1969). The theory of buyer behavior. New York, NY: John Wiley and Sons.

Ihtiyar, A., Ahmad, F. S., \& Osman, M. H. M. (2014). An Integrated Framework: Intercultural Competence, Service Quality and Customer Satisfaction in Grocery Retailing. Procedia - Social and Behavioral Sciences, 109, 492-496. https://doi.org/10.1016/j.sbspro.2013.12.495

Jones, T. O., \& Sasser, W. E. (1995). Why satisfied customers defect. Harvard business review, 73(6), 88-99.

Kant, R., \& Jaiswal, D. (2017). The impact of perceived service quality dimensions on customer satisfaction. International Journal of Bank Marketing, 35(3), 411-430. https://doi.org/10.1108/IJBM-04-2016-0051

Kheng, L. L., Mahamad, O., \& Ramayah, T. (2010). The impact of service quality on customer loyalty: A study of banks in Penang, Malaysia. International journal of marketing studies, 2(2), 57.

Kim, S.-H., Holland, S., \& Han, H.-S. (2013). A Structural Model for Examining how Destination Image, Perceived Value, and Service Quality Affect Destination Loyalty: a Case Study of Orlando. International Journal of Tourism Research, 15(4), 313328. https://doi.org/10.1002/jtr.1877

Latiff, K., \& Imm, N. S. (2015). The Impact of Tourism Service Quality on Satisfaction. International Journal of Economics \& Management, 9(S), 67-94.

Lau, M. M., Cheung, R., Lam, A. Y. C., \& Chu, Y. T. (2013). Measuring service quality in the banking industry: a Hong Kong based study. Contemporary management research, 9(3), 263-282.

Li, W., Pomegbe, W. W. K., Dogbe, C. S. K., \& Novixoxo, J. Dela. (2019). Employees' customer orientation and customer satisfaction in the public utility sector. African Journal of Economic and Management Studies, 10(4), 408-423. https://doi.org/10.1108/AJEMS-10-2018-0314

Lin, Y.-C., Lin, M.-L., \& Chen, Y.-C. (2017). How tour guides' professional competencies influence on service quality of tour guiding and tourist satisfaction: An exploratory research. International Journal of Human Resource Studies, 7(1), 1-19. https://doi.org/10.5296/ijhrs.v7i1.10602

Mawarni, I. A. S. D. (2019). Preferensi Pengunjung Dalam Konteks Perencanaan Destinasi Wisata Di Perbatasan Negara Studi Kasus: PLBN Motaain. Jurnal Teknologi dan Desain, 1(1), 1-12. 
McKercher, B., \& Prideaux, B. (2011). Are tourism impacts low on personal environmental agendas? Journal of Sustainable Tourism, 19(3), 325-345. https://doi.org/10.1080/09669582.2010.524702

Mulyana, A., \& Prayetno, S. (2018). Determinants of Customer Satisfaction and It's Implication on Customer Loyalty of Budget Hotel in DKI Jakarta. International Review of Management and Marketing, 8(6), 1-7. https://doi.org/10.32479/irmm.7144

Mwirigi, R. N. (2019). Mediating Effect of Service Quality on the Relationship Between Customer Relationship Management and Satisfaction of Commercial Banks' Account Holders In Nairobi City County, Kenya. technology, 11(9), 48-56. https://doi.org/10.7176/EJBM

Neal, J. D., \& Gursoy, D. (2008). A Multifaceted Analysis of Tourism Satisfaction. Journal of Travel Research, 47(1), 53-62. https://doi.org/10.1177/0047287507312434

Ninpradith, N., Viriyasuebphong, P., \& Voraseyanont, P. (2018). A Study of Tour Guide Competency, Service Quality, and Tourist Satisfaction of Chinese Tourist. Burapha Journal of Business Management Burapha University, 7(2), 106-121.

Parasuraman, A., Zeithaml, V. A., \& Berry, L. L. (1985). A Conceptual Model of Service Quality and Its Implications for Future Research. Journal of Marketing, 49(4), 4150. https://doi.org/10.1177/002224298504900403

Reichheld, F. F., \& Schefter, P. (2000). E-loyalty: your secret weapon on the web. Harvard business review, 78(4), 105-113.

Rosmika, T. E., \& Nurhaida, T. (2017). Employee Competence and Culture Set to Customer Satisfaction with Service Quality as Intervening Variable of PT. Bank Rakyat Indonesia (Persero) Tbk Medan. Journal of Education and Practice, 8(36), 45-53.

Saleem, H., \& Raja, N. S. (2014). The impact of service quality on customer satisfaction, customer loyalty and brand image: Evidence from hotel industry of Pakistan. MiddleEast Journal of Scientific Research, 19(5), 706-711. https://doi.org/10.5829/idosi.mejsr.2014.19.5.21018

Scott, M. L., Mende, M., \& Bolton, L. E. (2013). Judging the Book by Its Cover? how Consumers Decode Conspicuous Consumption Cues in Buyer-Seller Relationships. Journal of Marketing Research, 50(3), 334-347. https://doi.org/10.1509/jmr.11.0478

Seth, N., Deshmukh, S. G., \& Vrat, P. (2005). Service quality models: a review. International Journal of Quality \& Reliability Management, 22(9), 913-949. https://doi.org/10.1108/02656710510625211

Slack, N. J., \& Singh, G. (2020). The effect of service quality on customer satisfaction and loyalty and the mediating role of customer satisfaction . The TQM Journal, 32(3), 543-558. https://doi.org/10.1108/TQM-07-2019-0187

Spencer, L. M., \& Spencer, S. M. (1993). Competence at work: Models for a superior performance. Wiley.

Sung Moon, K., Kim, M., Jae Ko, Y., Connaughton, D. P., \& Hak Lee, J. (2011). The influence of consumer's event quality perception on destination image. Managing Service Quality: An International Journal, 21(3), 287-303. https://doi.org/10.1108/09604521111127974

Ţîţu, M. A., Răulea, A. S., \& Ţîţu, Ş. (2016). Measuring Service Quality in Tourism Industry. Procedia - Social and Behavioral Sciences, 221, 294-301. https://doi.org/10.1016/j.sbspro.2016.05.118 
Usman, L., \& Sairin, S. (2017). The Economic Functions of Cross-Border Activities of Skouw Sae Community, Jayapuraconomic Functions of Cross-Border Activities of Skouw Sae Community, Jayapura. KOMUNITAS: International Journal of Indonesian Society and Culture, 9(1), 150-160.

Vargo, S. L., \& Lusch, R. F. (2014). Evolving to a new dominant logic for marketing. Journal of Marketing, 68, 1-17.

Vinh, N. Q., \& Long, N. L. (2013). The Relationship Among Expectation, Satisfaction and Loyalty of International Visitor to Hanoi, Vietnam. Journal of global management, 5(1), 30-43.

Wei, C.-L., \& Ho, C.-T. (2019). Exploring signaling roles of service providers' reputation and competence in influencing perceptions of service quality and outsourcing intentions. Journal of Organizational and End User Computing (JOEUC), 31(1), 86109. https://doi.org/10.4018/JOEUC.2019010105

Wu, Y.-C., Tsai, C.-S., Hsiung, H.-W., \& Chen, K.-Y. (2015). Linkage between frontline employee service competence scale and customer perceptions of service quality. Journal of Services Marketing, 29(3), 224-234. https://doi.org/10.1108/JSM-022014-0058

Yeo, G. T., Thai, V. V, \& Roh, S. Y. (2015). An Analysis of Port Service Quality and Customer Satisfaction: The Case of Korean Container Ports. The Asian Journal of Shipping and Logistics, 31(4), 437-447. https://doi.org/10.1016/j.ajsl.2016.01.002 